\title{
Naturalistic study of the joint presence of headache and pets
}

\author{
D Moscato ${ }^{*}$, B Calabrese, FR Moscato \\ From The European Headache and Migraine Trust International Congress \\ London, UK. 20-23 September 2012
}

\begin{abstract}
Introduction
Pet Therapy is our first choice intervention for the therapy of children's headache, since in the majority of children in growing up age headache is often linked to a situation of psycho-social discomfort [1]. On the basis of several works, which had found that just the simple presence of pets was an improvement factor of the physical conditions of several patients $[2,3]$, we wanted to ascertain whether also the simple presence of pets (mammals) could be related to the development of childhood headache.
\end{abstract}

\section{Methods}

In a sample chosen in compulsory schools of our district we administered a questionnaire that would use (IHS, 2004) for the diagnosis of headache in the fifth year of primary school. The questionnaire, in addition to the data relating to the number of brothers and sisters and social conditions, indicated the presence of pets (mammals) in the family nucleus. results 477 children participated in the study (279f.198m. range 10-12 years), with diagnosis of Migraine $10.3 \%(8.4 \% \mathrm{MwA}, 1.9 \mathrm{MWA})$ Tension Type Headache17.4\%(FTTH14 \%, CTTH 3.5\%). No significant differences were found in the number of brothers and sisters, and in the social conditions. The presence of pets was equal to $18.4 \%$ of healthy children, whilst it was $4.3 \%$ in migraine sufferers, compared to $4.8 \%$ in children suffering from tension type headache.

\section{Conclusion}

The presence of animals in the house is significantly concurrent with a lower incidence of migraine and tension headache. The presence of pets in the house seems to be a factor of prevention of the onset of headache. From an epidemiologic standpoint, the interaction with a pet presupposes a difference of family lifestyle and a consequent

IDI Sanità, via Monti di Creta 10400165 Roma, Italy development in the coping modality, enabling to mitigate the arising of those etiological cognitive factors, which can promote headache suffering.

Published: 21 February 2013

\section{References}

1. Moscato D, Calabrese B, Moscato FR:. Cephalagia 2009, 29(suppl 1):105-106.

2. Duvall A, Nikolina M, Pychyl, Timothy A:. Anthrozoös 2010, 23(1):37-54.

3. Friedmann E, Thomas, Sue A, Son, Heesook, HAT Investigators:. Anthrozoös 2011, 24(3):273-285.

doi:10.1186/1129-2377-14-S1-P35

Cite this article as: Moscato et al: Naturalistic study of the joint presence of headache and pets. The Journal of Headache and Pain 2013 14(Suppl 1):P35.

\section{SpringerOpen ${ }^{\odot}$}

(C) 2013 Moscato et al; licensee Springer. This is an Open Access article distributed under the terms of the Creative Commons Attribution License (http://creativecommons.org/licenses/by/2.0), which permits unrestricted use, distribution, and reproduction in any medium, provided the original work is properly cited.
Submit your manuscript to a SpringerOpen ${ }^{\circ}$ journal and benefit from:

- Convenient online submission

- Rigorous peer review

- Immediate publication on acceptance

- Open access: articles freely available online

- High visibility within the field

- Retaining the copyright to your article

Submit your next manuscript at $>$ springeropen.com 